\title{
一般口演 16
}

\author{
除絩ラット灌流標本を用いた \\ 自発呼吸に伴う頸筋支配神経活動の解析 \\ Analysis of the nerve activity innervating the neck muscles \\ during the spontaneous respiration using in situ rat preparation \\ $\bigcirc$ 立川哲史 ${ }^{1,2)}$, 中山希世美 ${ }^{1)}$, 望月文子 ${ }^{1)}$, 中村史朗 ${ }^{1)}$ \\ 清本聖文 ${ }^{1)}$ ，飯島毅彦 ${ }^{2)}$, 井上富雄 ${ }^{1)}$ \\ Satoshi Tachikawa ${ }^{1,2)}$, Kiyomi Nakayama ${ }^{1)}$, Ayako Mochizuki ${ }^{1)}$, Shiro Nakamura ${ }^{1)}$ \\ Masaaki Kiyomoto ${ }^{1)}$, Takehiko Iijima ${ }^{2)}$, Tomio Inoue ${ }^{1)}$ \\ 1) 昭和大学歯学部口腔生理学講座 \\ 2) 昭和大学歯学部全身管理歯科学講座歯科麻酔科学部門 \\ ${ }^{1)}$ Department of Oral Physiology, Showa University School of Dentistry \\ ${ }^{2)}$ Department of Perioperative Medicine Division of Anesthesiology, Showa University School of Dentistry
}

\section{I. 目的}

全身麻酔導入時の偶発症に換気不全による高炭酸ガス 血症がある。高炭酸ガス血症が呼吸パターンの变化に 関与することは臨床的にも広く知られているが1), 吸息 時に連動して活動する気道上部の筋と横隔膜の筋活動の タイミングに与えている影響は明らかでない. 本研究で

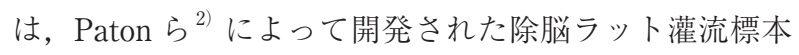
を用い，灌流液の二酸化炭素濃度を変化させる事によ り，横隔神経，上喉頭神経，舌骨下筋群を支配する第 一，第二頸髄神経の枝（C1-2）の活動がどのように変 化するのかを調べた。

\section{II. 方 法}

実験には生後 $3-4$ 週齢の Wistar ラット 5 匹を用い た.イソフルレンの吸入による麻酔下にて, 以下に示す 外科的手術を行い, 標本を作製した。 まず, 剣状突起直 上付近を基点とし胸壁の皮膚を剥離し，剣状突起から鎖 骨レベルまで吻尾方向に肋骨を切断することにより開胸 し, 抗凝固剤であるへパリン（1 ml，10 IU）をシリン ジを用いて心臓に注入した。 次に, 横隔膜直下で腹部を 切断して下半身を離断し, 水冷した人工脳脊䯣液に標本 を浸漬して仮死状態にした。呼吸と心拍の停止を確認し
た後, 開頭し, precollicular レベルで除脳を行った。次 いで全身の皮膚の除去, 両側肺実質の除去を行い, 記録 用チャンバーに標本を仰臥位にピンで固定した。下行大 動脈の断端からダブルルーメンカテーテル $(\phi 1.25 \mathrm{~mm}$, DLR-4, Braintree Scientific) を挿入し, カテーテルの先 端が 2,3 椎骨分進んだところに留置した後, チュービ ングポンプを用いて人工脳脊髄液をカテーテルのメイン ルーメンを介して送液し，体外循環法にて標本の灌流を 開始した。標本が自発呼吸を開始するまでは，1 分間に 循環血液量の $3-4$ 倍の灌流液が流れるように設定し, 自発呼吸開始後は徐々に全血量の 5 倍程度まで灌流液量 を増加させた。人工脳脊髄液の組成は, $125 \mathrm{mM} \mathrm{NaCl}$, $3 \mathrm{mM} \mathrm{KCl}, 24 \mathrm{mM} \mathrm{NaHCO}, 1.25 \mathrm{mM} \mathrm{KH}_{2} \mathrm{PO}_{4}, 1.25$ $\mathrm{mM} \mathrm{MgSO}_{4}, 2.5 \mathrm{mM} \mathrm{CaCl}, 10 \mathrm{mM}$ glucose とした。灌 流液は $95 \% \mathrm{O}_{2}-5 \% \mathrm{CO}_{2}$ 混合ガスで曝気する事により $\mathrm{pH}$ が約 7.4 になるように調整した人工脳脊髄液に, 膠質 浸透圧調整剂 (1.25\% Ficoll 70), 抗凝固剂 (10 IU ヘパ リン）を加えたものを使用した。灌流経路の途中にヒー ターコントローラー (TC-324C, Warner Instruments)

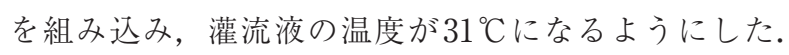
カテーテルのサブルーメンは圧トランスデューサーと接 続し，血圧を常にモニターした。

灌流開始後, 標本が自発呼吸を再開し, 呼吸運動や手 足の運動が起こってきた事を確認した後，筋弛緩剂（臭 
化ベクロニウム $2-4 \mu \mathrm{g} / \mu \mathrm{L}, 360 \mu \mathrm{L})$ を加え, 標本を 非動化した。横隔神経, 上喉頭神経，C1-2 剖出し， 吸引電極を用いて複合活動電位を記録した。コントロー ルとして 5 分程度の記録を行った後, 灌流液を $92 \% \mathrm{O}_{2}$ $-8 \% \mathrm{CO}_{2}$ 混合ガスで曝気した溶液（pH7.2） あるい は $90 \% \mathrm{O}_{2}-5 \% \mathrm{CO}_{2}-5 \% \mathrm{~N}_{2}$ 混合ガスで曝気した溶液 $(\mathrm{pH} 7.4)$ に 5 分間切り替えて, $\mathrm{CO}_{2}$ 濃度上昇および $\mathrm{O}_{2}$ 濃度低下の影響を観察した。

\section{III. 結果および考察}

下行大動脈に挿入したカテーテルを介して循環液の灌 流を開始すると，数分で自発呼吸が再開した。再開後す ぐの呼吸運動は胸郭のみであったが，時間と共に胸郭の 動きと同期して開口運動が加わった。標本を非動化した 後, 左側の横隔神経, 上喉頭神経, $\mathrm{C} 1-2$ 加複合活動 電位を記録したところ，横隔神経の吸息性活動とほほ同 期して上喉頭神経， $\mathrm{C} 1-2$ から神経活動が記録された

$\mathrm{CO}_{2}$ 濃度を上昇させたところ, 呼吸頻度は $0.32 \mathrm{~Hz}$ か ら $0.27 \mathrm{~Hz}$ に変化し, 平均 $15.1 \pm 9.5 \%$ 減少した。また, 吸息に一致した横隔神経, 上喉頭神経㧍よび $\mathrm{C} 1-2$ 活動 の振幅は，それぞれ $20.6 \pm 8.8 \%, 11.1 \pm 3.2 \%, 26.3 \pm$ 8.8\%増大した。横隔神経の吸息性活動を基準として各 神経の活動開始のタイミングを比較すると, $\mathrm{CO}_{2}$ 濃度の 上昇により，横隔神経の活動より上喉頭神経および $\mathrm{C} 1$ 2の活動が, より先行して見られるようになった。横隔 神経の活動開始から C1-2の活動開始までの時間は，コ ントロールで $0.28 \pm 0.03$ 秒であったのに対し, $\mathrm{CO}_{2}$ 濃度 を上昇させたことにより $0.83 \pm 0.04$ 秒となった。これら
の結果から, $\mathrm{CO}_{2}$ 濃度の上昇により中枢の化学受容野が 刺激され, 呼吸数の変動や神経活動の振幅の増大を引き 起こし，また頸部の筋肉と横隔膜の活動夕イミングに変 化を起こすことが示唆された。

$\mathrm{CO}_{2}$ 濃度上昇に用いる混合ガスでは $\mathrm{O}_{2}$ 分圧は低下す るので, $\mathrm{O}_{2}$ 濃度低下により末梢の化学受容器である頸 動脈小体，大動脈体が興奮し，呼吸パターンに影響する 可能性がある，そこで $\mathrm{CO}_{2}$ 濃度を変化させずに $\mathrm{O}_{2}$ 濃度 を低下させたガス $\left(90 \% \mathrm{O}_{2}-5 \% \mathrm{CO}_{2}-5 \% \mathrm{~N}_{2}\right)$ を用い て同様の実験を行った。その結果, 呼吸数, 横隔神経, 上喉頭神経, C1-2の神経活動の振幅, 神経活動の開始 のタイミングに有意な差は見られなかった。この事か ら, 循環血液量の 5 倍の灌流量では, $\mathrm{O}_{2}$ 濃度を $95 \%$ か ら $90 \%$ に低下させても末梢の化学受容器は影響を受け ないと考えられる。

以上の結果から, 生後 $3-4$ 週齢の除脳ラット灌流標 本において $\mathrm{CO}_{2}$ 濃度を上昇させ $\mathrm{pH}$ を変化させると, 呼 吸頻度の低下および舌骨下筋群の活動開始夕イミングが 早まることが明らかになった。このような変化は，高 $\mathrm{CO}_{2}$ 濃度負荷時の呼吸パターンの变化に対応していると 考えられる。

\section{N. 文献}

1 ）池上之浩, 田勢長一郎. Permissive hypercapnia. 蘇生 $2002 ; 21(2): 1-8$.

2 ) Paton, JFR. A working heart-brainstem preparation of the mouse. J Neurosci Methods 1996; 65: 63-68. 